\title{
PENGARUH MEDIA TUMBUH DAN LAMA PERENDAMAN TERHADAP PERKECAMBAHAN SORGUM VARIETAS NUMBU
}

\author{
Marsel Efraim Bajang*, A. Rumambi ${ }^{* *}$, W. B. Kaunang ${ }^{* *}$, D. Rustandi ${ }^{* *}$ \\ Fakultas Peternakan, Universitas Sam Ratulangi \\ E-mail :marsel_bajang@yahoo.com
}

\begin{abstract}
ABSTRAK
Penelitian pengaruh media tumbuh dan lama perendaman terhadap perkecambahan sorgum varietas numbutelah dilaksanakan. Tujuan penelitian ini adalah untuk mengetahui dan memperoleh data pengaruh media tumbuh tanaman dan lama perendaman terhadap perkecambahan tanaman sorgum. Penelitian ini menggunakan dua macam perlakuan yaitu media tumbuh dan lama perendaman. Rancangan yang digunakan adalah Rancangan Acak Lengkap (RAL) yang disusun secara faktorial yaitu $3 \times 4$ dengan 3 kali ulangan sehingga diperoleh 36 satuan percobaan, dimana faktor A yaitu media tumbuh yang terdiri dari 3 faktor dan faktor B yaitu lama perendaman dengan 4 faktor. Variabel yang diamati yaitu daya kecambah, laju perkecambahan dan jumlah daun. Hasil analisis keragaman menunjukan bahwa perlakuan media tumbuh memberikan pengaruh yang sangat nyata $(\mathrm{P}<0,01)$ terhadap daya kecambah dan laju perkecambahan. Interaksi media tumbuh dan lama perendaman memberikan pengaruh yang berbeda sangat nyata $(\mathrm{P}<0,01)$ terhadap jumlah daun.

Dapat disimpulkan bahwa media tumbuh memberikan respons positif terhadap daya kecambah dan laju perkecambahan sedangkan jumlah daun hijauan sorgum varietas numbu dipengaruhi oleh interaksi media tumbuh $100 \%$ tanah biasa dengan semua lama perendaman.
\end{abstract}

Kata Kunci: media tumbuh, lama perendaman, sorgum varietas numbu, perkecambahan.

*Alumni Fakultas Peternakan Unsrat

** Jurusan Nutrisi dan Makanan Ternak

\begin{abstract}
THE EFFECT OF GROWING MEDIUM AND SOAKING TIME ON GERMINATION OF SORGHUM VAR.

$N U M B U$. The present study was conducted to elaboratethe effect of the growing medium andsoaking times on germination of sorghum varieties numbu. This research has been done to learn and obtain data on the effect of the plant growth media and the soaking times of the sorghum plant sprouts. The experiment consisted of a $3 \times 4 \times 3$ factorial design with 3 levels of growing medium (100\% original soil; $50 \%$ original soil $+50 \%$ burned soil; and $100 \%$ burned out soil) and 4 levels of soaking times (0,2,4, and 6 hours). After a significant $F$ test (where necesarry) was employed to inspect differences among group means. Statistical difference was accepted at $\mathrm{P}<0,05$. Variables measured were: germination rates, germination, and leaf counts. Research results showed that growing medium gave a significant difference $(\mathrm{P}<0,01)$ on germination phase and germination rates. The interaction of growing medium andsoaking times gave a significant difference on leaf counts.It can be concluded that the growing medium gave a positive response on germination phase andgermination rates; while leaf counts of Sorghum var. Numbu interacted well with growing medium of $100 \%$ original soil and all level of soaking times.
\end{abstract}

Keywords: growing medium, soaking times, sorghum var. Numbu, germination. 


\section{PENDAHULUAN}

Sorgum merupakan salah satu jenis rumput-rumputan yang dapat dijadikan sebagai sumber hijauan yang cukup potensial untuk dikembangkan di Indonesia karena sorgum memiliki beberapa keunggulan yaitu, cepat tumbuhnya, potensi hasil tinggi dengan kualitas hijauan yang baik, biomasa tinggi serta daunnya dapat diawetkan dalam bentuk silase dan hay.

Sorgum yang umum digunakan dan ditanam di Indonesia adalah sorgum biji (grain sorghum), sorgum manis (sweet sorghum) dan broomcorn di kenal di Indonesia sebagai (hermada). Sorgum biji ( grain sorghum) paling cocok untuk pangan yang diolah menjadi tepung untuk bahan dasar kue, sebagai mediapertumbuhan jamur danpakan ternak. Sorgum manis (sweet sorghum) cocok digunakan sebagai pakan ternak (dibuat silase) dan bahan baku industri etanol. Broomcorn (hermada)cocok digunakan untuk membuat sapu terutama untuk diekspor ke jepang.

Di Indonesia, biji sorgum dikenal dengan berbagai nama daerah, antara lain yaitu jagung pari, cantel, gandum, oncer (jawa), jagung cetrik, gandrung, gandrum, degem, kumpay (sunda), dan gandum Minangkabau). Hasil analisa proximat laboratorium Sentral Ilmu Hayati (LSI)
Brawijaya Malang berdasarkan $100 \%$ bahan kering biji sorgum berturut-turut: Bahan kering $87 \%$; Protein kasar 10,26 $\%$; Serat kasar 2,72 \%; Lemak 2,70 \%; Ca 0,93; P 0,38 \%, dan Gross energy (Kkal/g) 4323,21 (Rumambi, 2013).

Biji sorgum mengandung senyawa fenolik yang terletak pada pada pericarp, testa, lapisan aleuron, dan endosperm , dimana senyawa fenolik banyak bermanfaat bagi kesehatan manusia. Sorgum hitam mengandung antosianin yang termasuk komponen flavonoid turunan poliphenol yang memiliki fungsi pemeliharaan kesehatan, diantaranya sebagai antioksidan, pencegah kelainan jantung koroner dengan mencegah penyempitan pembuluh darah arteri, dan pencegah kanker. Oleh sebab itu tepung sorgum dapat dianjurkan untuk dijadikan olahan pangan fungsional. Asupan antioksidan pada ternak ruminansia dapat meningkatkan motility dan viability sperma, dan dapat menurunkan peroksidasi lipid sehingga tidak menutup kemungkinan produktivitas daging dari ternak ruminansia yang mengkomsumsi sorgum akan terjaga kualitas dan kuantitas daging yang dihasilkan.

Komposisi daun sorgum setara dengan rumput gajah dan pucuk tebu yang masing-masing sebagai berikut: Protein kasar 7,82 \%, serat kasar 28,9\%. 
Sedangkan pada rumput gajah dan pucuk tebu masing - masing sebagai berikut : protein kasar $6 \%$ dan 5,33\%, serat kasar $34,25 \%$ dan 35,48\%. Dalam upaya memenuhi kebutuhan pangan, pakan, dan bahan industri yang terus meningkat, serta meningkatkan pendapatan petani maka pengembangan sorgum merupakan salah satu alternatif yang dapat dipilih. Benih bermutu baik akan menghasikan pertumbuhan bibit yang kuat dan perkembangan akar yang cepat.Secara morfologis suatu biji yang berkecambah umumnya ditandai dengan akar dan daun yang menonjol keluar dari biji.

Media tumbuh yang efektif merupakan salah satu faktor penentu perkecambahan, dimana media yang berpori, mampu mempertahankan kelembapan dan mampu memasok unsur hara, sangat baik untuk perkecambahan suatu benih.Air dapat membantu lapisan biji dan memfasilitasi pergerakan oksigen ke dalam biji dimana air merupakan media yang berperan dalam pemindahan material biji ke bagian lainnya yang dibutuhkan.Tanah dikatakan subur jika memiliki sifat fisika, kimia, dan biologi yang baik.

Tanah hasil bakaran adalah tanah sisa pembakaran bahan-bahan organik seperti ranting kering dan daun pepohonan yang kering. Tanah hasil bakaran bahan organik dapat digunakan dalam perkecambahan sebagai media yang baik. Dalam mempercepat proses perkecambahan benih perendaman dapat membantu dalam proses imbibisi air dan pengaktifan enzim untuk proses perkecambahan.

Berdasarkan pemikiran diatas perlu mengadakan penelitian untuk mengetahui dan memperoleh data tentang pengaruh perlakuan media tumbuh tanaman dan lama perendaman terhadap perkecambahan benih sorgum.

\section{MATERI DAN METODE PENELITIAN}

Bahan yang digunakan dalam penelitian ini yaitu benih sorgum varietas Numbu yang diperoleh dari Seameo Biotrop Bogor, tanah biasa dan tanah hasilpembakaran sampah organik dan air untuk perendaman. Alat yaitu, bambu untuk pembuatan rumah kecambah dan meja, paranet $75 \%$ naungan, ayakan tanah, cangkul, gergaji, bendrat, paku, tali, label, termometer, timbangan, sprayer, saringan, alat tulis menulis dan camera untuk dokumentasi.

Penelitian ini menggunakan Rancangan Acak Lengkap (RAL) yang disusun secara faktorial yang terdiri dari 2 faktor. Faktor A yaitu media tumbuh yang terdiri dari : 
A1: tanah biasa ;A2: $50 \%$ tanah biasa + $50 \%$ tanah hasil pembakaran ;A3: tanah hasil pembakaran sampah organik. Faktor B yaitu lama perendaman yang terdiri dari : P1: tanpa perendaman ; P2: 2 jam perendaman ; P3: 4 jam perendaman ; P4:6 jam perendaman. Perlakuan diulang sebanyak 3 kalisehingga diperoleh 36 satuan percobaan. Pada masing - masing media perlakuan menggunakan 20 benih, sehingga benih yang digunakan sebanyak 720 benih. Untuk analisis data menggunakan Program Ecxel 2010 dan Minitab versi 14.

\section{HASIL DAN PEMBAHASAN}

\section{Perlakuan Media Tumbuh Dan Lama Perendaman Terhadap Daya Kecambah}

Pengaruh perlakuan media tumbuh dan lama perendaman terhadap daya kecambah dapat dilihat pada Tabel 1. Nilai rataan terendah perlakuan media tumbuh dan lama perendaman terhadap daya kecambah diperoleh pada $\mathrm{A}_{2} \mathrm{P}_{1}$ yaitu sebesar $80,00 \%$. Sedangkan nilai rataan tertinggi perlakuan media tumbuh dan lama perendaman terhadap daya kecambah diperoleh pada media tumbuh $\mathrm{A}_{3} \mathrm{P}_{3}$ sebesar $100,0 \%$.

Hasil analisis keragaman menunjukkan bahwa perlakuan media tumbuh memberikan pengaruh yang berbeda sangat nyata $(\mathrm{P}<0,01)$ terhadap daya kecambah, sedangkan interaksi antara lama perendaman dan media tumbuh memberikan pengaruh yang berbeda tidak nyata $(\mathrm{P}>0,05)$ terhadap daya kecambah. Hasil uji lanjut dengan Tuckey Simultaneous Test tanaman yang ditanam pada media tumbuh $\mathrm{A}_{3}$ berbeda nyata $(\mathrm{P}<0,05)$ lebih cepat daya kecambahnya dibandingkan dengan media tumbuh $\mathrm{A}_{1}$ dan media tumbuh $\mathrm{A}_{2}$.

Tabel 1. Rataan Pengaruh Perlakuan Media Tumbuh Dan Lama Perendaman Terhadap Daya Kecambah Tanaman Sorgum

\begin{tabular}{cccccc}
\hline Perlakuan & P1 & P2 & P3 & P4 & Rataan \\
\hline A1 & 91,67 & 81,67 & 88,33 & 95,00 & $89,16^{\mathrm{a}}$ \\
A2 & 80,00 & 93,33 & 90,00 & 86,67 & $87,50^{\mathrm{a}}$ \\
A3 & 96,67 & 96,67 & 100,00 & 96,67 & $97,50^{\mathrm{b}}$ \\
\hline Rataan & 89,44 & 90,55 & 92,77 & 92,78 &
\end{tabular}

Ket: nilai pada lajur yang sama dengan superscript yang berbeda menunjukkan perbedaan yang nyata $(\mathrm{P}<0,05)$. 
Media tumbuh $\mathrm{A}_{3}$ dengan lama perendaman 4 jam memberikan respons tinggi lebih cepat daya kecambahnya dibandingkan dengan media tumbuh $\mathrm{A}_{1}$ dan $A_{2}$. Hal ini mungkin disebabkan karena tanah hasil bakaran (sampah organik) mengandung unsur hara makro $\mathrm{K}$ (kalium) yang tinggi.

Sampah organik merupakan sumber unsur hara tanah yang setelah mengalami proses dekomposisi akan tersedia bagi tanaman. Unsur hara kalium berpengaruh besar terhadap daya kecambah sorgum terutama pada benih tanaman sorgum (Siti Dan Wahyu, 2005).Kalium berfungsi sebagai penyusun protein dan karbohidrat pada tanaman, umumnya kalium berperan sebagai pengimbang pengaruh nitrogen dan phosphor. Menurut Rukmana (2005), K membuat tanaman lebih tahan terhadap penyakit dan dapat merangsang pertumbuhan akar untuk membantu daya kacambah tanaman sorgum. Cadangan makanan yang terdapat pada biji tanaman sorgum membantu pertumbuhan sorgum untuk berkecambah, setelah cadangan makanan di dalam biji habis maka sorgum akan menggunakan unsur hara yang ada di dalam tanah untuk berkecambah seperti unsur hara K (Sadjad, 1980). Rioardi (2006) menyatakan bahwa hasil Pembakaran sampah organik dapat menghasilkan unsur yang diperlukan oleh tanaman seperti kalium.

Tanah bakaran mempunyai porositas yang lebih baik dari tanah biasa sehingga tata udara tanah lebih baik. Porositas tanah juga mempengaruhi daya kecambah suatu benih karena pori-pori didalam tanah bakaran sampah organik menentukan banyak/sedikitnya kandungan air dan udara dalam tanah yang berfungsi untuk daya berkecambah suatu benih. Pada $\mathrm{pH}$ normal tanah terdiri dari $25 \%$ udara, $25 \%$ air, $45 \%$ mineral, dan $5 \%$ bahan organik.

Benih sorgum membutuhkan air yang cukup untuk melemahkan kulit biji, menghidrolisis cadangan makanan dan menaikkan kadar air benih dari sekitar $10 \%$ sampai tingkat $45 \%$, yang harus diperoleh sebelum perkecambahan di mulai (Kamil, 1996). Perendaman biji dalam air mengakibatkan kulit biji lembab dan lebih lunak memungkinkan pecah dan robek sehingga perkembangan embrio dan endosperm lebih cepat terjadi, serta untuk memberikan fasilitas masuknya oksigen kedalam biji (Kurnianingsih, 2012).

\section{Perlakuan Media Tumbuh Dan Lama Perendaman Terhadap Laju Percambahan}

Pengaruh perlakuan media tumbuh dan lama perendaman terhadap laju perkecambahan dapat dilihat pada Tabel 2. 
Tabel 2. Rataan Pengaruh Interaksi Perlakuan Media Tumbuh Dan Lama Perendaman Terhadap Laju Percambahan Sorgum

\begin{tabular}{cccccc}
\hline Perlakuan & P1 & P2 & P3 & P4 & Rataan \\
\hline A1 & 18,33 & 16,33 & 17,67 & 19,00 & $17,83^{\mathrm{a}}$ \\
A2 & 16,00 & 18,67 & 18,00 & 17,33 & $17,50^{\mathrm{a}}$ \\
A3 & 19,33 & 19,33 & 20,00 & 19,33 & $19,50^{\mathrm{b}}$ \\
\hline Rataan & 17,88 & 18,11 & 18,55 & 18,55 & \\
\hline
\end{tabular}

Ket : nilai pada lajur yang sama dengan superscript yang berbeda menunjukkan perbedaan yang nyata $(\mathrm{P}<0,05)$

Nilai rataan terendah perlakuan media tumbuh dan lama perendaman terhadap laju perkecambahan diperoleh pada $\mathrm{A}_{2} \mathrm{P}_{1}$ sebesar 16,00. Sedangkan nilai rataan tertinggi perlakuan media tumbuh dan lama perendaman terhadap laju perkecambahan diperoleh pada $\mathrm{A}_{3} \mathrm{P}_{3}$ sebesar 20,00 .

Hasil analisis keragaman menunjukkan bahwa perlakuan media tumbuh memberikan pengaruh yang berbeda sangat nyata $(\mathrm{P}<0,01)$ terhadap laju perkecambahan, sedangkan interaksi antara lama perendaman dan media tumbuh memberikan pengaruh yang berbeda tidak nyata $(\mathrm{P}>0,05)$ terhadap laju perkecambahan. Hasil uji lanjut dengan Tuckey Simultaneous Test tanaman yang ditanam pada media tumbuh $\mathrm{A}_{3}$ berbeda nyata $\quad(\mathrm{P}<0,05)$ lebih cepat laju perkecambahannya dibandingkan dengan media tumbuh $\mathrm{A}_{1}$ dan media tumbuh $\mathrm{A}_{2}$.

Media tumbuh $\mathrm{A}_{3}$ dengan lama perendaman 4 jam memberikan respons tinggi lebih cepat laju perkecambahannya dibandingkan dengan media tumbuh $\mathrm{A}_{1}$ dan $A_{2}$. Hal ini mungkin disebabkan oleh pengaruh media tumbuh $100 \%$ tanah hasil bakaran sampah organik terhadap perkecambahan suatu benih dan juga dipengaruhi oleh lama perendaman benih dalam air.

Pembakaran sampah organik secara alami dapat menghasilkan unsur yang diperlukan oleh tanaman seperti N, P, K, sehingga membuat benih dapat berkecambah dengan cepat (Dewi, 1996). Kandungan kalium yang tinggi didalam tanah bakaran organik mempengaruhi tingkat kecepatan suatu benih untuk dapat bertumbuh dengan cepat. Fungsi dari silika adalah menguatkan batang sehingga tanaman tahan rebah, memperkuat dinding jaringan epidermis pada biji selama proses perkecambahan dan mengurangi kekurangan air pada tanah bakaran organik. Fungsi dari unsur hara $\mathrm{N}$ adalah sebagai bahan pembangunan asam amino/protein/enzim dan asam nukleat, fungsi unsur hara $\mathrm{P}$ pada proses fisiologi 
dan biokimia tanaman yaitu untuk mengaktifkan proses metabolisme benih sehingga memungkinkan untuk dapat berkecambah (Hakim, 2007). Fungsi dari kalsium adalah merangsang pembentukan bulu-bulu akar agar benih lebih cepat untuk berkecambah serta berperan dalam pembuatan protein atau bagian yang aktif dari tanaman. Tanah hasil bakaran sampah organik pada mediatanam benih memiliki pengaruh yang cukup besar terhadap perbaikan sifat fisika tanah yang akan mempengaruhi kecepatan perkecambahan benih. Pengaruh tanah hasil bakaran sampah organik terhadap perbaikan sifat fisika tanah adalah peningkatan porositas tanah. Porositas tanah adalah ukuran yang menunjukkan bagiantanah yang tidak terisi bahan padat tanah dan terisi oleh udara dan air (Setiadi dan Yadi, 1992). Pori dalam tanah menentukan kandungan air dan udara dalam tanah untuk proses perkecambahan suatu benih (Stevenson, 1982).

Menurut Sumanto dan Sriwahyuni (1993), perkecambahan benih juga dipengaruhi oleh lama perendaman dalam air, semakin lama perendaman maka waktu perkecambahan juga akan semakin cepat. Perlakuan benih memberikan kecepatan tumbuh yang paling baik karena air dan oksigen yang dibutuhkan untuk perkecambahan dapat masuk ke benih tanpa halangan sehingga benih dapat berkecambah, semakin lama biji direndam, maka semakin besar masuknya air ke dalam endosperma biji, sehingga memungkinkan benih berkecambah dengan cepat tetapi ada batasan tertentu untuk lamanya perendaman karena jika terlalu lama direndam maka biji akan mengalami pembusukan dan rusak.

\section{Perlakuan Media Tumbuh Dan Lama Perendaman Terhadap Jumlah Daun}

Pengaruh interaksi perlakuan media tumbuh dan lama perendaman terhadap jumlah daun dapat dilihat pada Tabel 3. Nilai rataan terendah pengaruh interaksi perlakuan media tumbuh dan lama perendaman terhadap jumlah daun diperoleh pada $\mathrm{A}_{3} \mathrm{P}_{2}$ sebesar 2,08. Sedangkan nilai rataan tertinggi pengaruh interaksi perlakuan media tumbuh dan lama perendaman terhadap jumlah daun diperoleh pada $\mathrm{A}_{1} \mathrm{P}_{3}$ sebesar 3,00.

Hasil analisis keragaman menunjukkan bahwa perlakuan media tumbuh memberikan pengaruh yang berbeda sangat nyata $(\mathrm{P}<0,01)$ dan lama perendaman memberikan pengaruh yang nyata $(\mathrm{P}<0,05)$ terhadap jumlah daun, sedangkan interaksi antara media tumbuh dan lama perendaman memberikan pengaruh yang berbeda sangat nyata $(\mathrm{P}<0,01)$ terhadap jumlah daun. Hasil uji lanjut dengan Tuckey Simultaneous Test untuk melihat perbedaan antara perlakuan 
Tabel 3. Rataan Pengaruh Interaksi Perlakuan Media Tumbuh Dan Lama Perendaman Terhadap Jumlah Daun Tanaman Sorgum

\begin{tabular}{cccccc}
\hline Perlakuan & P1 & P2 & P3 & P4 & Rataan \\
\hline A1 & $2,95^{\mathrm{a}}$ & $2,79^{\mathrm{a}}$ & $3,00^{\mathrm{a}}$ & $2,91^{\mathrm{a}}$ & $2,91^{\mathrm{a}}$ \\
A2 & $2,74^{\mathrm{ab}}$ & $2,62^{\mathrm{ab}}$ & $2,83^{\mathrm{a}}$ & $2,24^{\mathrm{c}}$ & $2,61^{\mathrm{b}}$ \\
A3 & $2,29^{\mathrm{bc}}$ & $2,08^{\mathrm{c}}$ & $2,33^{\mathrm{bc}}$ & $2,62^{\mathrm{ab}}$ & $2,33^{\mathrm{c}}$ \\
\hline Rataan & $2,66^{\mathrm{ab}}$ & $2,50^{\mathrm{a}}$ & $2,72^{\mathrm{b}}$ & $2,59^{\mathrm{ab}}$ &
\end{tabular}

Ket: nilai pada lajur dan baris yang sama dengan superscript yang berbeda menunjukkan perbedaan yang nyata $(\mathrm{P}<0,05)$

diperoleh bahwa tanaman yang ditanam pada media tumbuh $100 \%$ tanah biasadengan lama perendaman 4 jam berbeda nyata $(\mathrm{P}<0,05)$ lebih banyak jumlah daunnya dibandingkan dengan media tumbuh $\mathrm{A}_{2}$ dan media tumbuh $\mathrm{A}_{3}$ pada berbagai lama perendaman.

Media tumbuh $100 \%$ tanah biasadengan lama perendaman 4 jam memberikan respons yang tinggi terhadap banyaknya jumlah daun dibandingkan $\mathrm{A}_{2}$ dan $\mathrm{A}_{3}$ pada berbagai lama perendaman. Hal ini mungkin disebabkan karena 100\% tanah biasa mengandung ketersediaan unsur hara dalam jumlah yang cukup dan seimbang.

Ketersediaan unsur hara dalam jumlah yang cukup dan seimbang merupakan faktor utama yang sangat menentukan tingkat keberhasilan pertumbuhan jumlah daun tanaman yang maksimum dan ditambahkan pula oleh Dwijoseputro (1992) yang menyatakan bahwa tanaman akan tumbuh subur apabila unsur hara yang dibutuhkan tanaman tersedia dalam jumlah yang cukup dan seimbang di dalam media tanam/tumbuh. Siklus unsur hara dan pembentukan struktur tanah yang stabil sangat mempengaruhi banyaknya jumlah daun dalam suatu tanaman. Unsur hara nitrogen berperan dalam membantu pertumbuhan vegetatif tanaman dan menyusun zat hijau daun (Abidin, 1993). Menurut Gardner et al.(1991), menyatakan nutrient dan ketersediaan air dapat mempengaruhi pertumbuhan seperti pada organ vegetatif juga dapat meningkatkan pertumbuhan jumlah daun. Untuk jumlah daun yang berpengaruh nyata akibat lama perendaman 4 jam benih dalam air erat hubungannya dengan faktor keadaan tanah atau lingkungannya. Menurut Salisbury dan Frank (1995), jumlah daun dipengaruhi oleh ketersediaan unsur hara di dalam tanah dan lama perendaman suatu benih di dalam air. Pada saat daun belum dapat berfungsi sebagai organ untuk fotosintesa maka pertumbuhan kecambah sangat tergantung pada persediaan 
makanan yang ada dalam biji (Dwidjoseputro, 1994).

Perkecambahan diawali dengan penyerapan air dari lingkungan sekitar biji, baik tanah, maupun media lainnya. Perubahan yang teramati adalah membesarnya ukuran biji yang disebut tahap imbibisi (berarti "minum"). Biji menyerap air dari lingkungan sekelilingnya, baik dari tanah maupun udara sehingga efek yang terjadi adalah membesarnya ukuran biji karena sel-sel embrio membesar dan biji melunak (Prawiranata, 1981).

\section{KESIMPULAN}

Daya kecambah dan laju perkecambahan tanaman yang terbaik adalah pada media tumbuh $100 \%$ tanah hasil bakaran sampah organik. Sedangkan jumlah daun yang terbaik diperoleh pada interaksi media tumbuh $100 \%$ tanah biasa dengan semua lama perendaman.

\section{DAFTAR PUSTAKA}

Abidin. 1993. Dasar-Dasar Pengetahuan Tentang Zat Pengatur Tumbuh. Angkasa. Bandung.

Dewi, W. S. 1996. Pengaruh Macam Bahan Organik dan Lama Prainkubasinya Terhadap Status P Tanah Andisol. MS. thesis, UGM,.Yogyakarta.
Dwijoseputro.1992.Fisiologi Tumbuhan dan Metabolisme Tanaman.Jakarta: Gramedia.

Dwijoseputro, 1994. Pengantar Fisiologi Tumbuhan. Gramedia Pustaka Utama, Jakarta.

Gardner F, Ravindran V, Cabahug, Farouk. 1991. Fisiologi Tanaman Budidaya. Cetakan ke 1. Jakarta : UI Press.

Hakim. 2007. Dasar - Dasar Ilmu Tanah. Universitas Lampung, Lampung.

Kamil, J, 1996. Teknologi benih. Angkasa Raya. Padang.Kurnianingsih. 2012. Pengaruh Suhu dan Lama Perendaman dalam Air terhadap Perkecambahan benih. Skripsi.Fakultas Sains dan Teknologi. Universitas Islam Negeri Maulana Malik Ibrahim Malang. Malang. 75 h.

Prawiranata. 1981. Dasar Dasar Fisiologi Tumbuhan Jilid II. Departemen Botani Fakultas Pertanian IPB, Bogor.

Rioardi. 2006. Unsur Hara yang Dibutuhkan Tanaman. Disadur dari http://rioardi.wordpress.com/2009/ 03/03/unsur-hara-dalam-tanahmakro-dan-mikro/. Pada 25 januari 2015 Pukul 13:57.

Rukmana, R. 2005. Usaha Tani Sorgum. Kanisius. Jakarta.

Rumambi, 2013. Karakteristik Pertumbuhan Sorgum Dengan Pemupukan Urea Berbeda Sebagai Sumber Nitrogen. Laporan Penelitian Unggulan Perguruan Tinggi (BPOTN) Universitas Sam Ratulangi, Manado. 
Sadjad. S. 1980. Panduan Pembinaan Mutu Benih Tanaman Kehutanan Di Indonesia. Proyek Pusat Pembenihan Kehutanan Direktorat Reboisasi dan Rehabilitasi Direktorat Jendral Kehutanan, Jakarta.

Salisbury dan B. Frank. 1995. Fisiologi Tumbuhan Jilid 3. Bandung : ITB Press.

Setiadi dan Yadi, 1992. Mikrobiologi Tanah. Petunjuk Laboratorium. Bogor: Departemen Pendidikan dan Kebudayaan Direktorat Jendral Pendidikan Tinggi, Pusat Antar Universitas Bioteknologi, Institut Pertanian Bogor.

Siti Yuhaeni Dan Wahyu H. 2005. Pertumbuhan Dan Produktivitas Tanaman Sorgum (Sorghum Numbu) Yang Mendapatkan Kombinasi N, P, K. Seminar Nasional Teknologi Peternakan dan Veteriner 2005. Balai Penelitian Ternak. Bogor
Steel, RGD dan J. H. Torrie 1992. Prinsip dan Prosedur Statistik, Gramedia. Pustaka utama, Jakarta.

Stevenson, F.T. 1982. Humus Chemistry. John Wiley and Sons, Newyork.

Sumanto dan Sriwahyuni, 1993. Pengembangan Benih Terhadap Perlakuan Perkecambahan. Pusat Penelitian dan Pengembangan Tanaman Industri. 